\title{
Use of the mind mapping learning model to improve the ability of students writing fantasy story text
}

\author{
Alna Royani ${ }^{1}$, Yessi Fitriani ${ }^{2}$, Darwin Effendi ${ }^{2}$ \\ ${ }^{1}$ Sekolah Menengah Pertama Negeri 13 OKU, Indonesia \\ ${ }^{2}$ Universitas PGRI Palembang, Indonesia
}

\begin{tabular}{l}
\hline Article Info \\
\hline Article history: \\
Received Jul $20^{\text {th }}, 2021$ \\
Revised Aug $12^{\text {th }}, 2021$ \\
Accepted Aug $30^{\text {th }}, 2021$ \\
\hline Keyword: \\
Writing \\
Fantasy stories \\
Mind mapping models \\
\end{tabular}

\begin{abstract}
This study aims to see the ability to write fantasy stories in Indonesian language learning with the mind mapping model of class VII-2 students at SMP Negeri 13 OKU in the 2020/2021 academic year. The approach used is a quantitative approach. This type of research is descriptive research. The data analysis in this study is the result of the assessment of student work, namely 2 assessors, namely assessor 1 and assessor 2 accompanied by an average. The results showed that the implementation of teacher learning was going well. Based on the research results, it can be concluded that the ability to write fantasy stories using the Mind Mapping model is in the ability category. Suggestions for this research are 1) so that grade VII students can improve their writing skills to get better results. 2) so that teachers of SMP Negeri 13 OKU can use an easy and precise learning model in the learning process. 3) so that other researchers can use this thesis as a reference source.
\end{abstract}

\section{Corresponding Author:}

Royani, A.,

Sekolah Menengah Pertama Negeri 13 OKU, Indonesia

Email: alnaroyani78@gmail.com

\section{Introduction}

Indonesian is the unitary language and official language of the Republic of Indonesia as well as the language of instruction in education in Indonesia. Therefore, teaching Indonesian needs to get attention from all parties. In addition, language is a means of communication by symbolizing thoughts and feelings to convey meaning to others. Learning language is learning to communicate, both oral and written . Language learning is intended for learning language skills. Someone is said to be skilled at language if they are skilled at listening, speaking, reading, and writing. Indonesian language learning should be directed at improving the ability of students to communicate in Indonesian well, both orally and in writing.

Indonesian language subjects are the minimum proficiency qualifications of students that describe the mastery of knowledge, language skills, and a positive attitude towards Indonesian (Ana, 2011: 10). Likewise in the 2013 Curriculum for Indonesian language and literature, it is stated that in learning narrative text (fantasy stories) it is intended that students are able to write the contents of fantasy stories in writing .

The role of writing skills is very important in everyday life. Therefore, writing skills should be possessed by students. With writing skills students can engage in various fields and activities. Of the various writing activities carried out by students, writing literature is an activity that is can increase students' ideas and imagination, one of which is by writing fantasy stories. The ability to write, especially writing fantasy stories, 
is in the 2013 curriculum, namely KD 4.4 presenting creative ideas in the form of fantasy stories verbally and in writing by paying attention to the structure and use of language.

The research was conducted at SMP Negeri 13 OKU because it was still found that the results of writing fantasy stories for grade VII students were still below the KKM. The low ability of writing fantasy stories in class VII SMP Negeri $13 \mathrm{OKU}$ is due to the fact that the teacher has not used an interesting learning model . Based on the existing problems, the researcher used the Mind Mapping learning model to improve the ability to write fantasy stories for seventh grade students of SMP Negeri 13 OKU .

Based on the results of observations at SMP Negeri $13 \mathrm{OKU}$, it was obtained data that the results of writing fantasy stories of grade VII students still needed to be improved with the Minimum Completion Criteria (KKM) standard of 70 which had been determined by the teacher at the school. For more gel asnya can be seen in tabe below:

Table 1<Daily Test Value Odd Semester for 2019/2020 Academic Year>

\begin{tabular}{ccccc}
\hline No. & Score & $\begin{array}{c}\text { Freq } \\
\text { uency }\end{array}$ & $\begin{array}{c}\text { Percen } \\
\text { tage }\end{array}$ & Criteria \\
$\mathbf{1}$ & $70-100$ & 24 & 68.57 & Completed \\
$\mathbf{2}$ & $\leq 69$ & 11 & 31.43 & Not complete \\
& Total & $\mathbf{3 5}$ & $\mathbf{1 0 0}$ & \\
\hline
\end{tabular}

(Source: Indonesian Language Teacher in 2020 )

From the table above, it can be seen that as many as 11 students (31.43\%) obtained scores below the Minimum Completion Criteria (KKM) and had to take remedials. From these data, it is time to improve learning by using learning methods or models that involve student activeness in the teaching and learning process that can make students more creative and innovative in understanding the material presented, one of which is the Mind Mapping learning model .

Mind Mapping is the easiest way to enter information into the brain, and to retrieve information from the brain. This method is a creative and effective way of taking notes so that it can be said that this mind mapping really maps the mind (Buzan, 2012: 6). Mind maps are a method of utilizing the whole brain by using visual imagery and other graphic infrastructure to form impressions. So, by imagining, imagining or imagining something by using the senses and connecting images with each other because mind mapping is full of images and colors.

This is also supported by the results of preliminary observations before the research that has been carried out by researchers, it can be seen that the mind mapping learning model is one of the learning models that teachers have applied as one of the learning revolutions that have been implemented by the government and contained in the latest curriculum, namely in 2013 curriculum.

Therefore the use of the mind mapping learning model is expected to improve the ability to write fantasy story texts, on this basis the authors are interested in conducting research with the title "Using Mind Mapping Methods to Improve the Ability to Write Fantasy Story Texts for Class VII Students of SMP Negeri 13 OKU "

\section{Method}

The research method is the method used by researchers in collecting research data (Arikunto, 201 4 : 16). The research method used is Action Research (PT) or what is also called classroom action research, because the class is a small part and an important part of the learning system in schools.

\section{Results and Discussions}

Researchers conducted classroom action ( classroom action research ) in two cycles. Each cycle is carried out in four stages which include: (1) planning and preparation for action; (2) the stage of implementing the action; (3) the observation stage; and (4) analysis and reflection stage.

Before carrying out the research, the researcher conducted a preliminary survey to determine the conditions in the field. Based on this survey activity, the researcher found that the quality of the process and the results of learning to write fantasy story texts in grade VII SMP Negeri 13 OKU was still low. This is indicated by the following: (1) there is still low student interest and motivation, (2) some students are still not used to using written media as a space to express their ideas and ideas, in other words students are not familiar with the 
tradition of writing In any written form, (3) some students need a long time to be able to express their ideas and ideas, especially to be able to describe in words about an object's description, (4) students have not been able to express ideas or ideas well, (5) ) students are less able to develop language, (6) students have not achieved mastery learning.

Furthermore, the researcher collaborated with class VII A teachers to overcome the problem by utilizing the Mind Mapping learning method in the learning process of writing fantasy story texts .

\section{Student Learning Outcomes}

In cycle 1, the application of the Mind Mapping learning method to the teaching and learning process in the classroom was carried out by the teacher. During the teaching and learning process, students seemed enthusiastic about following the students, considering that the teacher applied a learning model that invites games that emphasize student activity, so that students feel less embarrassed and as if they are playing while learning. The application is carried out by the teacher at the beginning of the perception, the Mind Mapping learning method step, and the final activity. During the teaching and learning process, one of the observers on behalf of Rosa Okta Narinda, S.Pd., made observations about the course of the teaching and learning process. The results of the observation showed that student activeness at the cycle meeting was included in the active category with an average value of $77.76 \%$, where the oral activeness score of $77.5 \%$ was included in the active criteria, the visual activeness value was $75 \%$ active, and the writing activeness score was 80.8 very active.

At the end of the meeting students were given a fantasy story text writing test to measure students' understanding and abilities. The overall test results obtained by the mean score of students were 70.47. This value has reached the target of the student's minimum completeness criteria as a whole, but for each student's value of $55.5 \%$ it still needs to be continued in cycle II to increase student scores through the Mind Mapping learning method.

The difficulty experienced by students in writing fantasy story texts in the first cycle was described in the results of the interview as follows.

"The difficulty in writing fantasy story texts is in the form of a lack of vocabulary to develop paragraphs that are in accordance with the existing topic, in composing it requires broad ideas and insights so that the developed paragraphs are easy to read"

The results of the interview indicated that the students still had difficulty developing paragraphs where they had minimal vocabulary, ideas and insights.

In the second cycle as a whole, the average score of students was 81.19 . From these data, it was obtained students who had the greatest score, namely 90 .This result showed that $88.8 \%$ of students who obtained the completeness of learning to write fantasy story texts using the Mind Mapping learning method, while the activeness of students in the second cycle were still assessed by the previous cycle observers. ie associate researcher on behalf of Rosa Okta Narinda, S.Pd., 5:57\% increase in the category (quite active) with a value of $80.8 \%$ verbal liveliness in the category very active, an increase of $3.3 \%$ in the second meeting, keakt ifan $80 \%$ visual entry in kat e gori very active, and the liveliness of writing $89.2 \%$ included in the category are very active, the result is an increase of $8.4 \%$ from the first cycle.

Students are already active in the teaching and learning process which is marked by activeness in each indicator which has increased from the previous cycle. Students have started to ask questions and actively express opinions to refute the statements and spell out the questions raised by other groups. With this increasing result and having obtained completeness above $85 \%$ indicates that there is no need to continue in the next cycle.

With the results of the research using the Mind Mapping learning method, it was obtained that the value increased from pre-cycle, cycle I and cycle II, so it could be concluded that the Mind Mapping method was effectively used in the learning process of writing fantasy story texts at SMP Negeri 13 OKU.

\section{Student Observation Results}

The observation method used to obtain data from student activities during the teaching and learning process was carried out using the Mind Mapping learning method, this was done to determine student skills (student activities) during the teaching and learning process with the Mind Mapping learning model taking place based on several indicators, namely:

Indicator 1 (visual activity) consists of three descriptors:

1. Students observe the learning media used by the teacher, 
2. Students pay attention to the teacher in explaining the material,

3. Students pay attention to their friends who are having an opinion.

Indicator 2 (oral activity) consists of three descriptors:

1. Students ask questions,

2. Students express opinions,

3. Students answer questions.

Indicator 3 (writing activities) consists of three descriptors:

1. Students note the material,

2. Students make conclusions,

3. Students do assignments.

Student activeness at the meeting in cycle I was included in the active category with an average value of $77.76 \%$, where the oral activeness score of $77.5 \%$ was included in the active criteria, the value of visual activeness was $75 \%$ active, and the value of writing activeness was 80.8 very active, and in cycle II student activeness experienced an increase of $5.57 \%$ in the category (quite active) where the value of oral activity was $80.8 \%$ in the very active category, an increase of $3.3 \%$ at the second meeting, $80 \%$ visual activeness was in the very active category, and $89.2 \%$ writing activeness was included in very active category, an increase of $8.4 \%$ from the first meeting.

The indicator that appears most often is the writing indicator, while the one that appears the least is the verbal indicator because students are still embarrassed to express their opinions, the average conclusion of student activities is $80.54 \%$.

From the two results above, both the test results and the observation results obtained values that go hand in hand, meaning that student scores tend to be low in the first cycle, but after the application of the Mind Mapping method, student scores have increased and have met the Minimum Completeness Criteria (KKM) in Language subjects. Indonesia, especially in the material of writing fantasy story texts at SMP Negeri 13 OKU.

This is because students have been given a learning process through the Mind Mapping learning method with several stages that stimulate students' activeness and understanding of the material presented. Model this learning has advantages as follows.

1. The learning is interesting, it encourages you to jump into it because this Mind Mapping learning model relies on speed in answering, so that it can motivate students and be interesting to follow, all students will be immediately motivated to participate directly in answering questions so that their group is not matched by other groups.

2. Train Cooperation. In implementing problem-based learning methods, students are asked to strengthen cooperation between groups so that each group can answer questions correctly and get points.

3. With the advantages possessed, it stimulates a good understanding of the material in students so that the value obtained increases compared to the first cycle.

Model learning Mind Mapping is one of the m odel effective learning, used in the teaching of writing text fantasy story in its c ap cycle. The effectiveness of the Mind Mapping learning model can be seen from several things, namely in terms of time, methods, and evaluation. This can be seen in the learning process.

The effectiveness of the Mind Mapping learning model in terms of time, namely learning in students is faster in capturing the material presented. The time used to produce a text writing fantasy story is also faster because students are more involved in and understand the writing process.

The use of the Mind Mapping learning model begins with finding the problem to be written by discussing it to find themes. After finding the problem, students identify the problem and formulate the problem in groups of 5-8 students, then the students look for data or sources that can make writing more complete by discussing it. The results of the steps above students then write and demonstrate according to the group, after that carry out writing editing and collect it. In conventional learning (without using any method) the teacher teaches like learning normally, that is, students are immediately given the task of writing fantasy story texts .

With a different learning method from conventional to Mind Mapping learning method, it can create an attraction for students. This interest makes students more motivated and has a strong desire to learn. In 
addition, students get new variations in learning activities so that students are interested in writing fantasy story texts . Students' interest can be seen from several things, namely a sense of curiosity about something new about experiences and events they have experienced.

According to Johnson cited Sanjaya (2012: 217) describes 5-step M odel learning Mind Mapping :

1. Defines the problem. Formulate problems from certain events that contain conflict until learners are clear about the problem being studied. In this case the teacher asks for the opinions of students about the problem that is being studied.

2. Diagnosing the problem determines the causes of the problem.

3. Formulate alternative strategies.

4. Test each action that has been formulated through class discussion.

5. Determine \& implement preferred strategies.

6. Making decisions about which strategy to undertake.

7. Conduct evaluation. Both process evaluation and outcome evaluation.

Arends (quoted by Mashuri, 2013: 24) suggests the following steps for the Mind Mapping learning model .

1. Student orientation to the problem. The teacher conveys the learning objectives, explains what logistics (materials and tools) are needed for problem solving and provides motivation for students to pay attention to problem solving activities.

2. Organizing students. The teacher helps students define and organize learning so that it is relevant to problem solving.

3. Guiding individual and group investigations. The teacher encourages students to find appropriate information, conduct experiments, and seek explanations and problem solving.

4. Develop and present results. The teacher assists students in planning and delivering results in accordance with the given assignment;

5. Analyze and evaluate the problem solving process and results. The teacher helps students to reflect on the results of their investigations and the learning processes that have been implemented.

According to Amala (2013: 25) an American education expert explained the six steps in this Mind Mapping learning model, namely as follows.

1. Formulate problems. The teacher guides students to determine problems to be solved in the learning process, even though the teacher has actually determined the problem.

2. Analyze the problem. The steps of students critically review the problem from various points of view.

3. Formulate a hypothesis. The steps of the students to formulate various possible solutions according to their knowledge.

4. Collecting data. The steps of students looking for and describing various information needed to solve problems.

5. Hypothesis test. The steps of students in formulating and drawing conclusions are in accordance with the acceptance and rejection of the proposed hypothesis.

6. Formulate problem-solving recommendations. The steps of students describe recommendations that can be made according to the formulation of the results of hypothesis testing and the formulation of conclusions.

In terms of evaluation, in the early stages of writing fantasy text, students still made many mistakes, both in terms of vocabulary, grammar of the graphs and so on. This Mind Mapping learning model can improve students' fantasy story text writing skills. With this learning method students can find the problems to be told, and have discussions to collect data, making it easier to put it in writing. The results of the improvement in student writing can be seen in the aspect of describing the facts in sentences that are good, developing sentences into paragraphs is good, logical sequence, sentences are effective and spelling is good. 
The success of this learning model in improving the quality of the process and learning outcomes of fantasy story text can be seen from the following indicators.

1. The quality of the learning process to write fantasy story texts increases

Actions in the form of the application of the fantasy story text method carried out in each cycle were able to improve the quality of the learning process of writing fantasy story text for seventh grade students of SMP Negeri 13 OKU . The improvement in terms of the learning process can be seen in the following indicators

a. Increased student activity

The activeness of students in learning to write fantasy story texts has increased from cycle to cycle. Indicators of student activity in the learning process include student activeness in asking questions, responding to appreciation, listening to explanations from the teacher, and enthusiasm for doing assignments given by the teacher.

b. Increased student attention and interest

Student attention and interest in the learning process is very important. To grow and maintain this, teachers need to stimulate students by applying new, unique, or commonly used methods. One way that teachers can use is through the use of learning models . In this study, teachers utilize m odel learning Mind Mapping . After the act of utilizing this method, students' attention in learning to write fantasy story texts increased. Student interest and interest increase after the teacher provides motivation at the beginning of learning with rewards for students who are most active in learning and students who get the highest score.

c. Increased teacher skills in managing the class

The teacher's ability to manage the classroom is one of the determinants of success in a learning process. Class management carried out by the teacher, among others, is in the form of giving attention to all students, giving rewards and punishments to students, presenting material by combining lecture methods with other methods that make students not saturated in participating in learning, utilizing learning media, and motivating students to be active in learning. learning.

When the researcher carried out the initial survey activity, it was found that the classroom management carried out by the classroom teachers was not good. This can be reflected in the ind ic ator as follows:

a. Teachers are less able to arouse students' interest and motivation to be active in learning.

b. The position of the teacher is more often than not standing in front of the class.

c. Teachers do not give reward and punishment to students.

d. Teachers are less able to create pleasant learning situations for students.

After the action was carried out, little by little the teacher's weakness began to decrease. The ability of teachers to manage classes is increasing. Teachers are no longer stuck in learning activities that must be carried out in the classroom. The teacher no longer acts as a teacher who fully controls the class but rather acts as a facilitator in learning. Teachers arouse student interest and motivation by providing rewards for students who get good grades. In addition, the teacher also provides punishment for students who do not pay attention to the lesson.

2. The quality of learning outcomes in writing fantasy story texts increases

Based on the preliminary survey that had been lexised, as a whole it could be concluded that the students' writing skills were still low. The low writing skills are indicated by the following indicators: 1) there is still low student interest and motivation, 2) some students are still not used to using written media in any form of writing, 3) most students need a long time to be able to pour ideas and ideas especially to be able to describe in the form of words about the description of an object, 4) students have not been able to express ideas or ideas well, 5) students are less able to develop language, 6) use less potential words.

After action by applying $\mathrm{m}$ odel learning Mind Mapping on material written text fantasy story to be increased, it can be seen from: (1) the increased interest and motivation to participate in learning, (2) the results of the students' shows that there has been an increase in writing skills student fantasy story text . Judging from the content, the students 'writing in cycle II was much better than the previous cycle, (3) the emergence of students' creativity and imagination in arranging sentences into good writing, (4) there was a correspondence between the writing and the object depicted. 
Thus, it can be concluded that the teaching of writing text fantasy story through learning methods Mind Mapping has been successful in improving students' ability k e las VII SMP Negeri 13 OKU in essay writing text fantasy story. This has changed student behavior in a positive direction with the understanding and ability of students in writing fantasy story texts obtained through the actions of cycle I and cycle II.

\section{Conclusions}

Based on the results of the research that has been done, it can be concluded as follows: 1) The test results in the first cycle obtained that the average score of the students had not reached the target of the Minimum Completeness Criteria as applied in SMP Negeri $13 \mathrm{OKU}$, the scores of these students can be seen in the scores of each student. For that, it is necessary to continue in the second cycle to increase student grades through the Mind Mapping learning method . 2) In the second cycle, it was obtained an average score that reached the overall completeness. From $\mathrm{h}$ acyl this which shows that students gain mastery learning in writing the text of the story fantas i methods Mind Mapping, so no need to proceed to the next cycle. 3) Based on the results of the two data above, both test results data and student learning activities, there has been an increase, so it can be concluded that the ability to write fantasy story texts in Indonesian subjects has increased after the application of the Mind Mapping method at SMP Negeri 13 OKU.

\section{References}

Akhiria. 2019.Pengaruh Strategi Pembelajaran Mind Mapping Terhadap Keterampilan Menulis Deskripsi Peserta Didik Kelas V di MIN 7 Bandar Lampung. Jurnal : Unviersitas Bandar Lampung: Tidak Dipublikasikan.

Ngalimun. 2013. Strategi dan Model Pembelajaran. Sleman Yogyakarta: Aswaja Pressindo.

Nugraheni, Sri Aninditya. 2012. Penerapan Strategi Cooperative Learning. Yogyakarta: Pedagogia.

Nurgiyantoro, Burhan. 2016. Penilaian Pembelajaran Bahasa Berbasis Kompetensi. Yogyakarta: BPFEYogyakarta.

Riduwan. 2011. Penelitian untuk Peneliti. Jakarta: Erlangga.

Riduwan. 2012. Penelitian untuk Peneliti. Jakarta: Erlangga.

Shoimin, Aris. 2014. 68 Model Pembelajaran Inovatif dalam Kurikulum 2013. Jakarta: Ar- Ruzz Media.

Slavin, E Robert. 2015. Cooperative Learning Teori, Riset dan Praktik. Bandung: Nusa Media.

Sugiyono. 2017. Metode Penelitian Kuantitatif, Kualitatif dan R\&D. Bandung: Alfabeta.

Sukardi. 2009. Evaluasi pendidikan. Jakarta: PT Bumi Aksara.

Suparno. 2017. Keterampilan Menulis. Jakarta: Universitas Terbuka.

Suprijono, Agus. Cooperative Learning Teori dan Aplikasi Paikem. Yogyakarta: Pustaka Pelajar. 